\title{
Non-Secretory Multiple Myeloma in a Hemodialysis Patient with Hypercalcemia
}

\author{
Hiperkalsemi Saptanan Hemodiyaliz Hastasında Nonsekretuar Multipl \\ Miyelom Tanisı
}

\author{
Fatih Mehmet Erdur ${ }^{1}$, Yasemin Usul Soyoral ${ }^{1}$, Habib Emre ${ }^{1}$, Hüseyin Beğenik ${ }^{1}$, \\ Mehmet Taşdemir ${ }^{2}$, Reha Erkoç ${ }^{3}$ \\ ${ }^{1}$ Department of Nephrology, School of Medicine, Yuzuncu Yil University, Van, Turkey \\ ${ }^{2}$ Department of Internal Medicine, School of Medicine, Yuzuncu Yil University, Van, Turkey \\ ${ }^{3}$ Department of Nephrology, School of Medicine, Bezmialem University, Istanbul, Turkey
}

\section{To the Editor,}

Multiple myeloma (MM) develops due to clonal expansion of malign plasma cells. Abnormal plasma cells secrete abnormal immunoglobulins that can be detected monoclonally (M peak) in serum and/or urine via electrophoresis. MM manifests clinically and radiologically with anemia, hypercalcemia, renal failure, and lytic lesions in bones [1]. When the characteristic MM clinical and radiological findings are observed, but there is no monoclonal $\mathrm{M}$ peak based on electrophoresis, it is known as non-secretory multiple myeloma (NSMM) - a rare variant of MM [2,3]. NSMM is observed $1 \%-5 \%$ of all MM patients [4]. Hypercalcemia, which can present as mild to severe and life threatening, is the most common metabolic abnormality associated with MM, occurring in approximately 33\% of patients [5]. Herein we report a patient diagnosed with NSMM after detecting hypercalcemia during follow-up 7 months after the start of hemodialysis treatment.

A 62-year-old male presented to our hospital with a 1-month history of left knee-joint pain. This patient began peritoneal dialysis following the diagnosis of chronic renal failure (CRF) 7 months earlier at another hospital, and then 1 month later began hemodialysis due to resistant peritonitis. Written informed consent was obtained from the patient. Physical examination findings were as follows: blood pressure: 100/60 mmHg; pulse: $90 \mathrm{bpm}$; temperature: $36.7^{\circ} \mathrm{C}$; respiration rate: 18 breaths $\mathrm{min}^{-1}$. Except for left knee-joint tenderness and movement restriction, examination of all other systems was normal. X-ray imaging of the left knee-joint was normal. Laboratory findings were as follows: hemoglobin: $8.3 \mathrm{~g} \mathrm{dL}^{-1}$; MCV: 91.2fL; urea: $105 \mathrm{mg} \mathrm{dL}^{-1}$; creatinine: $8.39 \mathrm{mg} \mathrm{dL}^{-1}$; corrected calcium: $14.92 \mathrm{mg} \mathrm{dL}^{-1}$ (normal range: 8.4-10.7 $\mathrm{mg} \mathrm{dL}^{-1}$ ); phosphorus: $5.1 \mathrm{mg} \mathrm{dL}^{-1}$; total protein: $5.71 \mathrm{~g} \mathrm{dL}^{-1}$; albumin: $3.0 \mathrm{~g} \mathrm{dL}^{-1}$; globulin: $2.7 \mathrm{~g} \mathrm{dL}^{-1}$; sedimentation: 40 $\mathrm{mm} \mathrm{h}^{-1}$; parathormone: $6.6 \mathrm{pg} \mathrm{mL}^{-1}$ (normal range: $15-68$ pg $\left.\mathrm{mL}^{-1}\right)$.

The patient was hemodialyzed with calcium dialysate $1.25 \mathrm{mmol} \mathrm{L}^{-1}$ and was hydrated. Steroid and zoledronic acid were initiated because the corrected calcium level increased to $17.12 \mathrm{mg} \mathrm{dL}^{-1}$. On d 5 of treatment the calcium level returned to normal (9.3 mg dL -1). The patient's history of using drugs containing vitamin $\mathrm{D}$ and calcium was negative. Malignancy screening showed no pathological findings. Abdominal ultrasonography showed that kidney size was within the normal range. We performed protein electrophoresis due to the suspicion of MM in this patient with hypercalcemia, a positive CRF history, and normal kidney size. Monoclonal gammopathy was not observed in serum and urine protein electrophoresis, or immunofixation electrophoresis. Osteolytic bone lesions

\section{Address for Correspondence: Fatih Mehmet ERDUR, M.D.,}

Yüzüncü Yıl Üniversitesi, Tıp Fakültesi, Eğitim ve Araştırma Hastanesi, Nefroloji Kliniği 65300 Van, Turkey

Phone: +90 4322150470 E-mail: drfme@yahoo.com

Received/Gelis tarihi : April 21, 2011

Accepted/Kabul tarihi : February 21, 2012 
were observed via pelvic X-ray. Examination of specimens obtained via bone marrow aspiration and biopsy showed diffuse interstitial plasma cell infiltration (35\% plasma cells). Immunohistochemical examination showed CD38 and kappa ( $\kappa)$ staining in infiltrative plasma cells, but no lambda $(\boldsymbol{\lambda})$ staining. The patient was diagnosed as NSMM and referred to the hematology clinic.

In conclusion, in end-stage CRF patients with undefined hypercalcemia and bone pain, radiographically observed lytic bone lesions, and normal kidney size, but no M peak based on electrophoresis NSMM should be considered, and bone marrow aspiration and biopsy should be performed.

\section{Conflicts of Interest Statement}

None of the authors of this letter have any conflicts of interest, including specific financial interests, relationships, and/or affiliations, relevant to the subject matter or materials included.

\section{References}

1. Laubach J, Richardson P, Anderson K. Multiple Myeloma. Annu Rev Med 2011; 62: 249-264

2. Bourantas K. Nonsecretory multiple myeloma. Eur J Haematol 1996; 56: 109-111

3. Doster DR, Folds J, Gabriel DA. Nonsecretory multiple myeloma. Arch Pathol Lab Med 1988; 112: 147-150

4. Kyle RA, Gertz MA, Witzig TE, Lust JA, Lacy MQ, Dispenzieri A, Fonseca R, Rajkumar SV, Offord JR, Larson DR, Plevak ME, Therneau TM, Greipp PR. Review of 1027 patients with newly diagnosed multiple myeloma. Mayo Clin Proc 2003; 78: 21-33

5. Oyajobi BO. Multiple myeloma/hypercalcemia. Arthritis Res Ther 2007; 9 (Suppl 1): S4 